
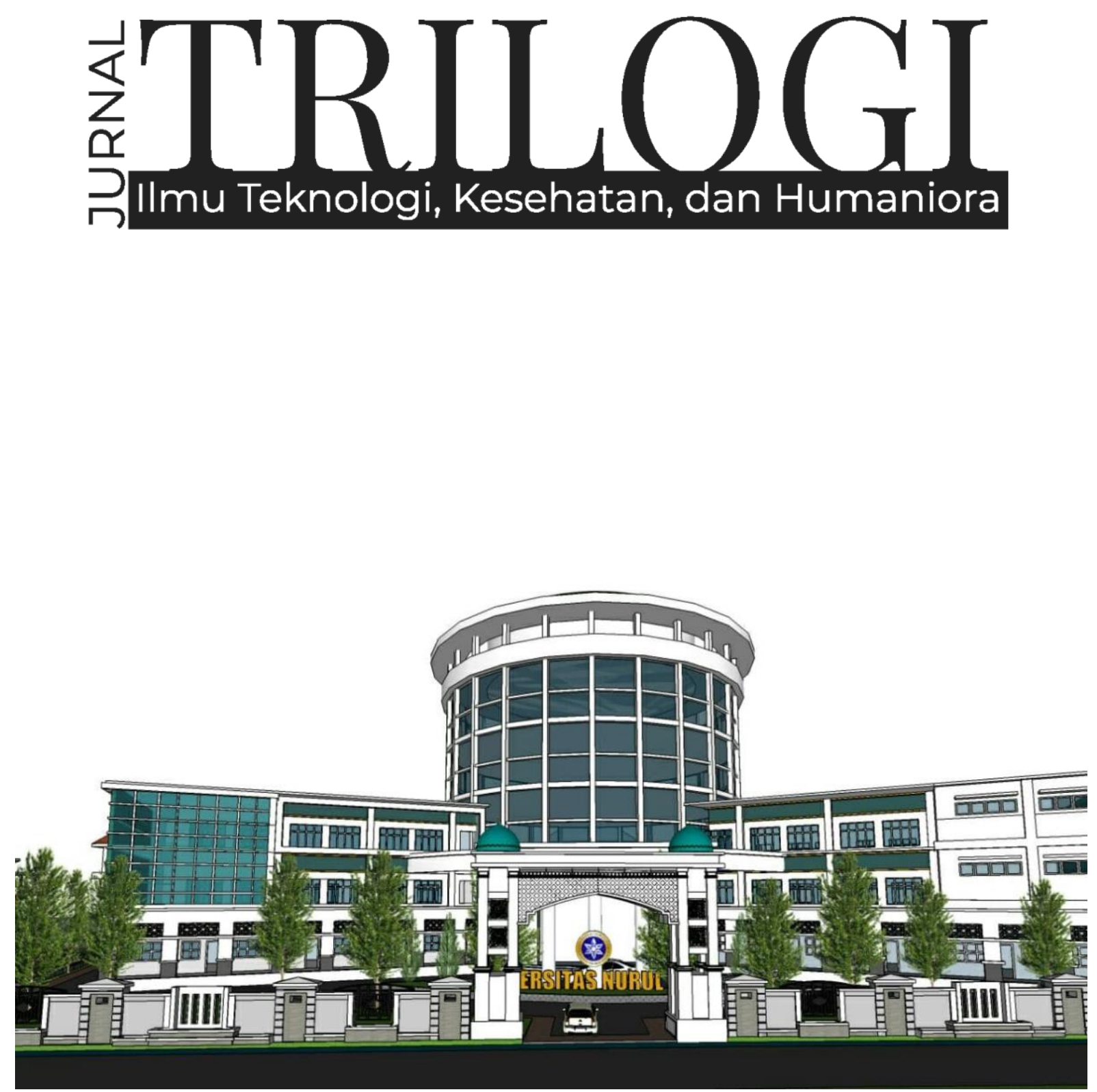

PENGEMBANGAN PENDIDIKAN DAN EKONOMI PESANTREN DI MASA PANDEMI COVID-19 


\section{犃BUOGI}

Vol. 2, No. 2, 2021

Editor in Chief

Achmad Fawaid, (SCOPUS ID: 57214837323)

\section{Managing Editors}

Hasan Baharun, (ID SCOPUS : 57200983602)

Sugiono Sugiono, (SCOPUS ID : 57199578160)

Ismail Marzuki, (SCOPUS ID: 57201500245

Subhan Rachman, (SCOPUS ID: 57192937912)

Nurul Huda, (SINTA ID: 6119615)

Syamsuri, (SINTA ID: 6116825)

Ridhatullah Assya'bani, (SINTA ID: 6200862)

\section{Peer Reviewers}

Miftahul Huda, (SINTA ID: 6171566), University of Antwerp, Belgium

Achmad Naufal Irsyadi, (SINTA ID: 6704870), Universitas Nurul Jadid, Indonesia

Gulpi Qorik Oktagalu P., (SINTA ID: 5982074) Universitas Nurul Jadid Probolinggo, Indonesia Hozairi, (SINTA ID: 166198), Universitas Islam Madura, Indonesia

Nur Hamid, (SINTA ID : 6744813), Univeristas Nurul Jadid Probolinggo, Indonesia Zainal Munir, (SINTA ID: 6672512), Universitas Nurul Jadid Probolinggo, Indonesia Sri Astutik Andayani, (SINTA ID: 6172559), Universitas Nurul Jadid Probolinggo, Indonesia Sukamto Sukamto, (SINTA ID: 5979034), Universitas Widya Gama Malang, Indonesia Deny Utomo, (SINTA ID: 6016108), Universitas Yudharta Pasuruan, Indonesia Fariz Alnizar, (SCOPUS ID: 6659824), UNUSIA Jakarta, Indonesia

Fuad Rahman, (SCOPUS ID: 57201474778), UIN Sulthan Thaha Saifuddin Jambi, Indonesia Saifuddin Zuhri Qudsy, (SCOPUS ID: 57213595165), UIN Sunan Kalijaga Yogyakarta, Indonesia Akhmad Anwar Dani, (SINTA ID: 14305), IAIN Surakarta, Indonesia

Maufur Maufur, (SINTA ID: 5989329), IAIN Kediri, Indonesia

Siti Mahmudah Noorhayati, (SINTA ID: 6726997), IAIN La Roiba Bogor, Indonesia Busro Busro, (SCOPUS ID: 57205022652), UIN Sunan Gunung Djati Bandung, Indonesia Akmal Mundiri, (SCOPUS ID: 57205059378), UNUJA Probolinggo, Indonesia

\section{Section Editor}

Ahmad Zubaidi, Universitas Nurul Jadid, Probolinggo, Indonesia 
TRILOGI: Jurnal IImu Teknologi, Kesehatan, dan Humaniora is a peer-reviewed journal, open-access journal which publishes original articles on various issues within technology, health, and social humanities, which include but are not limited to newrenewable energy, food-agriculture, health-pharmacy, transportation, informationcommunication technology, advanced-materials, maritime-infrastructre, social-artseducation, and religious studies based on academic and scientific research.

TRILOGI: Jurnal IImu Teknologi, Kesehatan, dan Humaniora seeks to publish a balanced mix of theoretical or empirical articles, case studies, review papers, comparative studies, exploratory papers, and book reviews. All accepted manuscripts will be possibly published both online and in printed forms.

Editorial Office:

TRILOGI: Jurnal IImu Teknologi, Kesehatan, dan Humaniora Lembaga Penerbitan, Penelitian, dan Pengabdian kepada Masyarakat (LP3M) Universitas Nurul Jadid, Paiton, Probolinggo, Jawa Timur, Indonesia 67291.

Phone: 088830 77077, Hp: 082318007953

Email: jurnal.trilogi@gmail.com

Website: https://ejournal.unuja.ac.id/index.php/trilogi/index 


\section{Tables of Content}

71-76

Pengaruh Metode Pembelajaran Daring dengan Aplikasi Google Classroom terhadap Hasil Belajar Siswa Madrasah Ibtidaiyah Nurul Mun'im Paiton Probolinggo

Feriska Listrianti, Lailatul Munawwaroh, Sayyidatul Arifa, Siti Aisyah

77-84

Inklusivitas dan Responsivitas Pesantren dalam Penanganan Pandemi Covid 19: Telaah Hidden Curriculum Pembelajaran di Pondok Pesantren Nurul Jadid

Zakiyah BZ, Uswatun Hasnah, Nafistur Rahmah

84-94

Integrasi Kurikulum Madrasah Diniyah dengan Lembaga Formal dalam Meningkatkan Mutu Lulusan di Sekolah Menengah Pertama (SMP) Nurul Jadid Paiton Probolinggo

Abdurrahman, Ika Fitri Anwar, Sofiya Mauliza, Nadya Afkarina

95-104

Some Issues on Time Deposit Financing: An Islamic Perspective on Mudharabah Agreement at Baitul Maal wa Tamwil (BMT) NU in Randuagung Lumajang

Saifuddin, Abdul Hafid, Hengki Wahyu Pratama

$105-110$

Analisis Pengembangan Potensi Ekonomi Keluarga melalui Unit Usaha Kapuk

Fahrudin, Iis Sa'diyah, Rizaldi Chandra Gunawan

111-117

Penguatan Ekonomi Pesantren melalui Pengembangan Ekonomi Masyarakat Pesisir: Pelajaran dari Pondok Pesantren Nurul Jadid Paiton Probolinggo

Achmad Febrianto, Muhammad Habibullah, Aksal Ilhamsyah

118-125

Prevensi Perilaku Konsumtif Persepektif Abraham Maslow dan Tri Logi Santri

Muhammad Syaiful Suib, Habibatur Rizkiyah, Fitria Nur Ain 
$126-136$

Manajemen Pengembangan Kurikulum Berorientasi pada Pembentukan Karakter

Moh Rifa'i, Fatimah Al Zahra, Abdurrahman Abdurrahman, Mukhlisin Saad

137-147

Home Industry, Kaderisasi, dan Santripreneur

Muh Hamzah, Aprilinda Dwi Kurniawati, Husnul Khotimah

148-157

Rancangan Pengelolaan Nirsampah Mandiri Skala Lembaga Pendidikan

Tirmidi, Eril Sinta Nuriyah, Rofi'ah

158-166

Parents' Knowledge and Commitment To Stimulate Child Development

Lailatul Fitriyah, Nurul Islamiyah, Auliya' Fatahillah

167-172

Implementasi Pembelajaran Akhlak Berbasis Multikultural pada Masa Pandemi di Madrasah Tsanawiyah Nurul Jadid Paiton Probolinggo

Abdullah, Yusrolana, Nur Laily

$173-183$

Implementasi Evaluasi Pembelajaran Daring (Online) melalui Home Visit

Moch Tohet, Moh. Bagus Abdillah, Adam Hakim Al Rizki

184-192

Efektivitas Pembelajaran Luring pada Mata Pelajaran Matematika selama Pandemi Covid-19

Zaenol Fajri, Sukron Junaidi, Hamdani Alfarisi 
P-ISSN: 2774-4574; E-ISSN: 2774-4582

TRILOGI, 2(2), Mei-Agustus 2021 (95-104) @2021 Lembaga Penerbitan, Penelitian, dan Pengabdian kepada Masyarakat (LP3M) Universitas Nurul Jadid Paiton Probolinggo

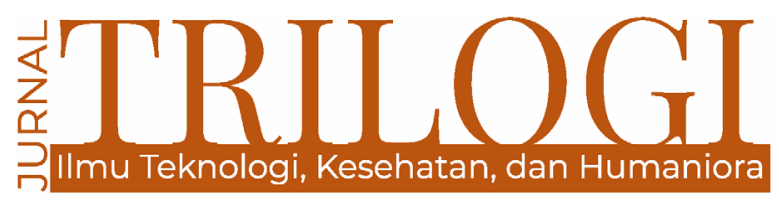

\title{
SOME ISSUES ON TIME DEPOSIT FINANCING: An Islamic Perspective on Mudharabah Agreement at Baitul Maal wa Tamwil (BMT) NU in Randuagung Lumajang
}

\section{Saifuddin}

Universitas Nurul Jadid, Probolinggo

Saifuddin.unuja@gmail.com

\section{Abdul Hafid}

Universitas Nurul Jadid, Probolinggo

chafid023@gmail.com

Hengki Wahyu Pratama

Universitas Nurul Jadid, Probolinggo

hengkiwahyu876@gmail.com

\begin{abstract}
This research aims to find out the Law Survey and the application of term deposits in the Mudharabah Akad on the BMT NU branch of Randuagung Lumajang. This research uses qualitative descriptive methods with two data collection techniques, interviews with General Manager, Account Officer, Teller and members, and documentation of other literature relevant to the research problem being scrutinized. The results of this study are the implementation of term deposits in the Mudharabah Akad on BMT NU branch of Randuagung Lumajang Lumajang at the Fatwa of the National Syariah Hall Number 03 / DSN-MUI / IV / 2000. The client as property owners (Shahibul Maal) and BMT as lenders through Mudharabah Akad (Mudharib). This contract uses mudharabah muthharabah muthlaqah, the savings member does not provide any conditions to BMT. In this contract, the shared profit distribution (ratio) is given ahead or at the beginning of the contract, where for direct proceeds to the account of the saver. From the aspect of Islamic law, the implementation of the Mudharabah agreement with the addition of savings is not accurate, because the method for these results is calculated based on funds from Shahibul Maal or a member of the saver, until his division becomes fasakh (damaged)
\end{abstract}

Keywords: Baitul Maal Wa Tamwil, Mudharabah, Deposit savings 


\begin{abstract}
Abstrak:
Penelitian ini bertujuan untuk mengetahui tinjauan hukum dan penerapan deposito berjangka dalam akad mudharabah pada BMT NU Cabang Randuagung Lumajang. Penelitian ini menggunakan metode deskriptif kualitatif dengan dua teknik pengumpulan data, yakni wawancara dengan general manager, account officer, teller serta anggota dan dokumentasi terhadap literatur lain yang relevan dengan masalah penelitian yang diteliti. Hasil penelitian ini adalah pelaksanaan deposito berjangka dalam akad mudharabah pada BMT NU Cabang Randuagung Lumajang berpedoman pada fatwa Dewan Syariah Nasional Nomor 03/DSN-MUI/IV/2000. Penabung sebagai pemilik harta (shahibul maal) dan BMT sebagai pemberi pinjaman melalui akad mudharabah (mudharib). Akad ini menggunakan akad mudharabah muthlaqah, yakni anggota simpanan tidak memberikan syarat apapun kepada BMT. Dalam akade ini, pembagian keuntungan bersama (nisbah) diberikan di depan atau di awal akad, di mana bagi-hasil langsung masuk ke rekening anggota penabung. Dari aspek hukum Islam, pelaksanaan akad mudharabah dengan penambahan saldo tabungan tidaklah tepat, karena metode bagi-hasil ini dihitung berdasarkan dana dari shahibul maal atau anggota penabung, sehingga pembagiannya menjadi fasakh (rusak)
\end{abstract}

Katakunci: Baitul Maal wa Tamwil, Mudharabah, tabungan deposit

\section{Introduction}

Islam is a perfect religion that regulates aspects of human life both in faith, worship, morals and muamalah. Islam enforces the economic system and its entire life system based on the principle of tawhid which aims to uphold economic balance in the life of individuals and society. Thus the Islamic economic system seeks to alleviate human life from the threat of struggle, division due to competition, anxiety and chaos and tranquility, leading to a peaceful and serene life under the auspices of Allah SWT.

In shari'ah there are two contracts: first the tabarru' contract, which is a contract whose purpose is for goodness only with the aim of helping (ta'awun) and its orientation is to get the pleasure of Allah SWT and secondly, the tabarru' agreement, which is a contract that aims to gain worldly benefits, Generally, this contract can be considered valid if there is a qabul consent between the parties, and the worldly benefits contained in the gair tabarru 'contract vary, including business benefits (tamwil / tijarah). Among other things, business activities are carried out through agreements which are expected to bring benefits (Putri, 2020).

Business development with the syari'ah system is evidenced by the development of shari'ah business institutions in the form of: 1) the establishment of syari'ah banks in the form of Shari'ah Commercial Banks (BUS), Syari'ah Business Units (UUS) in conventional commercial banks and Syari'ah People's Financing Bank (BPRS), 2) establishment of Baitul maal Wat Tamwil (BMT) which is engaged in the financing sector for small and medium-sized entrepreneurs, 3) establishment of shari'ah financing companies (which are engaged in, among other things, shari'ah leasing), a shari'ah insurance-reinsurance company and 4) the establishment of a syari'ah securities company that operates in the shari'ah capital market (Mas'udah, 2017).

Banking has an intermediary function between the owners of money (deposit of funds) and channeling it to entrepreneurs. Distribution of syari'ah banking funds is based on three principles: 1) buying and selling (al-ba'i), 2) profit sharing, 3) ijarah (rent / wages). First, channeling the donation using the principle of al-ba'i is carried out, among others, by means of the mudharabah and istishna contracts; second, the distribution of funds based on the profit sharing principle, among others, is carried out by means of a syirkah and mudharabah agreement and thirdly, the distribution of funds based on the ijarah principle is carried out by means of an ijarah agreement and Ijarah Mumtahiya Bit Tamlik (IMBT), among others. Meanwhile, banking services are carried out by means of a hawalah (debt transfer) contract, wakalah bil ujrah and kafalah (Hamidah \& Yandono, 2017). 


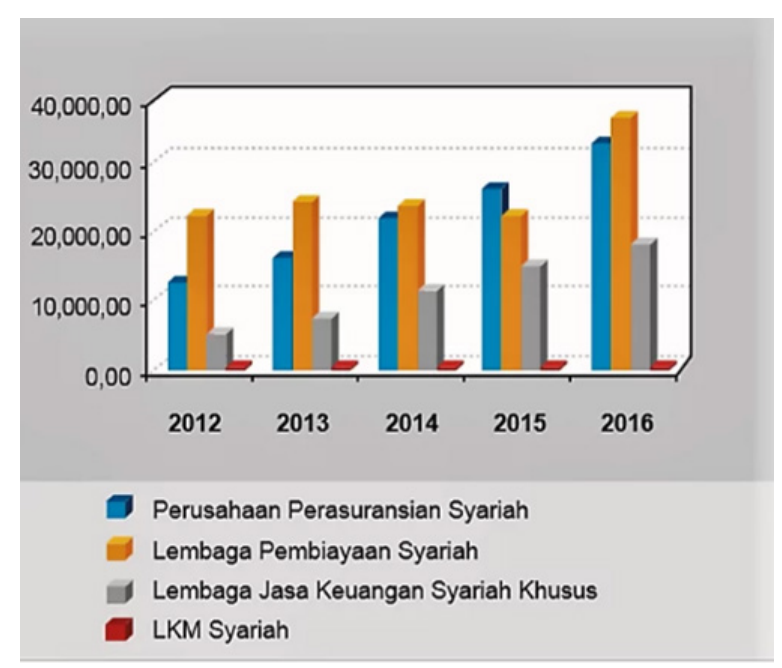

Figure 1. Total asset development LKS 2012-2016

Source: (Otoritas Jasa Keuangan, 2012-2016)

With human needs in today's development, Baitul maal Wat Tamwil (BMT) has developed a lot and has products that are needed by today's modern society that are in accordance with shari'ah. Baitul maal wat tamwil (BMT) consists of two terms, namely baitul maal and baitut tamwil. Baitul maal is more directed at efforts to collect and distribute non-profit funds, such as: zakat, infaq and shadaqah. Meanwhile, baitut tamwil is an effort to collect and distribute commercial funds (Heradhyaksa \& Markom, 2018).

The collection of funds that is directly related to the calculation of the distribution of business results is the collection of funds using the mudharabah principle or contract (mudharabah mutlaqah / unrestricted investment) because syari'ah banks apply the principle of profit sharing with the owners of these mudharabah funds. With the existence of contracts that are in accordance with the shari'ah, humans in carrying out their business will be free and avoid usury, maisir, gharar, and immorality. So that people will be more honest and will be more blessed in running their business (Trisanty, 2018).

Every human being wants his property to have added value. So that he always tries to develop the assets he owns, either by turning it around in the world of trade, or by investing in certain fields. Meanwhile, sometimes as an owner, someone does not have the ability to develop it, so he needs other people to help him or by doing cooperation. On the other hand, it is also inversely proportional, someone who has expertise does not have the capital to develop his expertise. From here, an agreement is made in developing the business, so that it can be mutually beneficial. One type of cooperation in Islam is what is known as mudarabah (in other terms it is also called qiradh). This is a solution that can be done, people who have sufficient assets but have the skills to cultivate assets through the efforts they do. This is one of the forms of social relations that Islam hopes for, namely the weak help the weak (Afkar, 2017).

Mudharabah is a collaboration between two parties to run a particular business or business, where one party owns the capital, then the other party operates the business. If there is a loss, it is the owner of the capital that shall bear the whole loss, unless the loss occurs due to the negligence of the party running the business, while if the business gets a profit, it is divided according to the agreement between them. With the condition that the profit may not be calculated based on a percentage of the total capital given by sahibul maal. The profit sharing calculation must be based on the benefits obtained. Mudaraba profit is the amount obtained as an excess of capital (Khotijah, 2020)obtained from the Otoritas Jasa Keuangan (OJK. Whereas in the practice of implementing the mudharabah contract at BMT NU Branch of Randuagung Lumajang, the profit sharing from the savings is divided at the beginning / in advance at the time of the contract.

Based on the above problems, the purpose of this study is to determine the legal review and application of time deposits in the mudharabah contract at BMT NU Branch of Randuagung Lumajang.

\section{Method}

\section{a. Model Development}

This study was descriptive qualitative research. It describes, summarizes various conditions, situations or social phenomena that exist in society and attempts to draw that reality to the surface as characteristics, characters, characteristics, models, signs or descriptions of certain conditions, situations or phenomena. Qualitative research is also called naturalistic research because the research is carried out in natural conditions because the data collected and the analysis are more qualitative in nature (Harahap, 2008) between two or more parties. The problems of contract of mudharabah financing arises when owners of capital requires collateral to be met by businesses. Imposition guarantees in classical fiqh that developed by the mazhab of Imam 
that in terms of mudharabah financing, capital owners cannot demand collateral from businesses to recoup the principal or capital plus profit. If the owners of capital require the provision of collateral from mudharib and make collateral as a condition of a contract then the cooperation contract is null and void according to Maliki and Shafi'i. According to the Hanbali, and Abu Hanifah, only the conditions were null and void, while contract itself remains valid. In general, according to Law No. 21 Year 2008 on sharia banking, collateral is termed by rahn and kafalah. This is in line with the DSN-MUI Fatwa formulating collateral consists of Rahn and kafalah. It should be understood that the contract of mudharabah financing is different from the concept of financing debts that require no collateral. When syariah banking is applying guarantee in the contract of mudharabah financing, it will lead to another problem that is interest to be discussed. This research applies a legal normative method by approach legislations and Fatwa DSN-MUI, this allows the researcher to find the answer about the problems that are considered correct.", "author" : [ \{ "dropping-particle" : "", "family" : "Harahap", "given" : "Mhd Yadi", "non-droppingparticle" : "", "parse-names" : false, "suffix" : "" \} ], "container-title" : "Journal of Islamic Studies", "id" : "ITEM-1", "issue" : "1", "issued" : \{ "date-parts" : [ [ "2008" ] ] \}, "page" : "1-14", "title" : "The Implementation Of Collateral In The Con-Tract Of Mudharabah Financing According To Act No. 21 Of 2008 On Sharia Banking And DSN-MUI's FATWA", "type" : "article-journal", "volume" : "1" \}, "uris" : [ "http://www.mendeley. com/documents/?uuid=a7a0a55e-a491-41849835-b9e1e7fd0048" ] \} ], "mendeley" : \{ "formattedCitation" : "(Harahap, 2008.

This research was conducted with a specific practical objective, namely to take certain steps as a policy or model that is considered effective in implementing mudharabah contract financing. And to arrive at the above provisions, the researcher tries to combine the system of exploration, description and explanation, namely an effort to explore the phenomena that exist in the society involved in the research and then try to describe and describe the character of the community being studied and so on to explain why it can happen in society. In addition, literature is also part of qualitative research because the data obtained in it cannot be quantified (Lutfiyah Hastuti, Harahap, 2014)it was financing is not optimal as expected by the scientists of Islamic law. Research for this first year aims; (1.

The approach used in this research is a multidisciplinary approach, namely the normative legal approach (syar'i) where this approach is used to analyze legal provisions derived from the Qur'an and hadith as well as figh studies on problems related to the pawn concept in sharia rules. Then the sociological approach, where this approach is used to examine the condition of the community by applying the practiced paddy pawn pattern (A Suhaeli Fahmi, Widodo Farid Ma'ruf, 2015).

\section{b. Data}

Data analysis in qualitative research is carried out during data collection and after completing data collection within a certain period. In qualitative data analysis is carried out interactively and continues to completion, so that the data is saturated and data that is considered credible are obtained. The data analysis steps in this study are as follows:

\section{1) Data Reduction}

Data reduction means summarizing, selecting the main things, focusing on the important things, looking for themes and patterns and removing unnecessary. Thus the data that has been reduced will provide a clearer picture, making it easier for researchers to collect further data and search for it if necessary. This data reduction is concerned with the process of selecting, focusing, simplifying, abstraction and changing the crude data contained in the oral form from field notes.

\section{2) Presentation of Data}

After reducing the data, the data are described in brief descriptions which form a narrative text. So that it will make it easier to understand the location and the next steps taken. Presentation of data, namely, presentations as a set of structured information that gives the possibility of drawing conclusions and taking action.

\section{3) Withdrawal of conclusions}

After the data is processed properly, the researcher needs to draw conclusions. Drawing conclusions is the final activity in data analysis and from the results of the conclusions the researcher will know the answers to the problems under study. 


\section{Result and Discussion}

\section{a. Financing}

The definition of financing in general is the provision of money or an equivalent claim, based on an agreement or agreement between the bank and another party which requires the financed party to return the money or claim after a certain period of time in exchange for profit sharing. Credit according to the term credit in English means lending money, credo in Roman means trust, the term above is taken from the science of figh which is taken from the term qard. Whereas qard in figh means lending money on the basis of belief. Thus, from some of the above definitions it can be concluded that financing is the provision of money or an equivalent bill based on mutual trust to support an investment activity that has been planned by requiring the financed party to return the money or claim within a certain period of time. in return or for the results (Qomar, 2018).

Financing provided by financial institutions such as banks must be based on trust, thus basically the provision of financing is giving trust to the trusted party in receiving the financing (Yuliana \& Bashir, 2017). The elements contained in the provision of a financing facility are:

a. Trust, which is the confidence of the financier that the financing provided (in the form of money, goods, or services) will actually be received back in a certain future. This trust is given by the bank, where previously investigative research has been carried out on customers both internally and externally. Research and investigations on the past and present conditions of the financing applicant customers.

b. The agreement, in addition to the element of trust in the provision of financing / credit, also contains an element of agreement between the lender and the recipient of the credit. This agreement is set forth in an agreement in which each party signs their respective rights and obligations.

c. Period, each financing or credit given has a certain period of time, this period includes the agreed credit repayment period. This period of time can be in the form of short term, medium term or long term.

d. Risk, The risk is that there is a grace period for repayment that will cause a risk of noncollection / default of credit provision. The longer the financing / credit, the greater the risk and vice versa. This risk is borne by the bank, whether it is a deliberate risk by a negligent customer or an unintentional risk. For example, there is a disaster or the bankruptcy of a customer's business without any other element of intent.

e. Remuneration, is an advantage for providing a financing or service which we know as interest. The remuneration in the form of interest and credit administration fees is the bank's advantage. Meanwhile, for banks based on sharia principles, the remuneration is determined by profit sharing.

\section{b. Contract}

The word akad comes from Arabic, namely ar-rabtu which means connecting or linking, or binding between several ends of something (Muslimah, 2019). According to the Akad language it has several meanings, including:

a. Tying (ar-rabtu), or gathering in two ends of a rope and tying one of them in another way so that they are connected, then the two become part of a piece of matter,

b. The connection (aqdatun) or connection that holds both ends and ties them together,

c. Promise (al-ahdu)

According to the term (terminology), what is meant by a contract is an agreement between consent and qabul which is justified by the syara 'which determines the pleasure of both parties or the gathering of handovers between the two parties or the words of a person which affects both parties (Muhyidin, 2017).

According to the terminology of figh scholars, the contract can be viewed from two aspects, namely in general and specifically. In general, the meaning of a contract according to the opinion of the scholars of Syafi'iyah, Malikiyah, and Hanabilah, namely everything that a person does based on his own desires, such as waqf, divorce, liberation, or something whose formation requires the desire of two people such as buying and selling, representation and pawning. The definition of a contract in a special meaning is an agreement that is determined by consent-qabul based on the provisions of syara 'which affects the object or the association of the words of one person who contracts with another in syara' on the visible aspect and has an impact on the object. An example of a consent is a statement from a seller, "I have sold this item to you." or 
"I'll leave this item to you." For example qobul, "I bought your stuff." or "I received your item". Thus, Ijab-qabul is an act or statement to show a pleasure in acting between two or more people, so as to avoid or get out of a bond that is not based on syara '. Therefore, in Islam not all forms of agreement or agreement can be categorized as a contract, especially agreements that are not based on pleasure and Islamic law (Hsb, 2017).

\section{c. Mudharabah}

Mudaraba is linguistically derived from the ضرب ضرب, following the wazan مفاعلة, which signifies the work carried out by two or more parties. Mudharabah is a contract that is carried out by two parties, the owner of the capital (shahibul maal) and the business actor who runs the capital (mudharib). The word mudharabah comes from the word al-dharb fi al-ardhi, namely business in commerce. Mudaraba is also called qiradh, which comes from the word qardhu with the meaning of qath'u (deduction), because the owner of the capital deducts part of his property to be traded for profit (profit) (Usanti, 2019).

From some of the above opinions, it can be concluded that mudharabah is the handover of assets from the owner of the capital / property to the manager to be collected, the profits are shared according to the agreed agreement, while the losses are only borne by the owner of the capital. The manager does not bear material losses because he has borne other losses in the form of energy and time (Astutik, 2018). There are two types of mudaraba, namely as follows:

a. Mudharabah mutlaqah is someone who gives capital to others without certain conditions. He said, "I give this capital to you to do mudaraba, and the profit is for us together evenly" or divided by three (two thirds and one third), and so on.

Mudharabah muqayyadah is a mudharabah contract in which the owner of the capital determines one of the above. For example, for other people to mudaraba on condition that they manage it in a certain country, or certain goods, or for a certain time, or not to sell and buy except from certain people.

\section{d. BMT NU}

BMT NU was born out of a concern over the condition of the people of Sumenep in general and the people of Gapura sub-district in particular where their welfare had not significantly improved. Even though their work ethic is quite high, this is in line with the Madura song asapok angen abantal ombek (covered in the wind and cushioned by the waves). Is the community of the district Gapura district. Sumenep is a hard workers, husband and wife work hand in hand to make ends meet, but their hard work is not able to improve their standard of living. This is what makes Nahdlatul Ulama concerned. Therefore, in 2003 the MWC Management. NU Gapura assigned to the Economic Institution, which at that time acted as Chairman of the Economic Institution, Masyudi. Departing from a mutual agreement, the Economic Institution finally launched the Community Economic Strengthening Program for Community Welfare, which is Mardhatillah. Of course, this desire requires concrete, systematic, and integrated efforts to overcome the various economic problems of the citizens (Zaamah, 2019).

From the workshop, it was finally found that the problems faced by the small community were weak access to capital, weak marketing, and weak mastery of technology. Furthermore, the workshop participants agreed that what needed to be tackled first was strengthening capital for small and micro enterprises that had so far lacked access to capital and were controlled by large investors or rent-seeking practices that tended to choke their businesses.

Masyudi, as the chairman of the NU Economic Institute at that time, offered the idea of establishing Baitul Maal wat Tamwil (BMT), as a sharia microfinance institution engaged in the savings and loan business for its members. This idea departed from a concern about the increasingly rampant loan shark practices. Information received by Masyudi at that time, as many as 3,311 small traders in the Gapura District and its surroundings were caught in the practice of moneylenders and "daily banks", with interest rates of up to 50 percent a month.

Initially, the workshop participants and the NU Gapura MWC Management objected to the idea of the head of an economic institution to establish a BMT. Their objections are not without reason, one of the fundamental reasons for them is because of the trauma of the past which is often formed by financial institutions, in the end their money is misused. Finally, on June 1, 2004, the MWC NU management together with the workshop participants agreed on an idea to establish a syari'ah savings and loan business called BMT 
NU (Baitul Maal wa Tamwil Nahdlatul Ulama). However, based on the decision of the MWC NU Gapura Executive Meeting on April 292007 at the KH. Dahlan Gapura Barat, the name BMT Nahdlatul Ulama was changed to BMT Nuansa Umat which was shortened to BMT NU. The name change was based on input from the notary and officials from the District Cooperative and UMKM Office. Sumenep, that the name Nahdlatul Ulama may not be used by other institutions without written idzin from the Nahdlatul Ulama Executive Board.

BMT NU Savings Products in between:

a. Member Savings (SIAGA)

SIAGA is KSPP Owner's Savings. SHARIA. This product uses the Musharaka Akad.

b. Mudlarabah Time Deposit (SIBERKAH)

SIBERKAH is a savings account with abundant profits with a profit sharing of $65 \%$. This product uses the Mudlarabah Muthlaqah Agreement.

c. Wadi'ah Time Deposit (SAJADAH)

SAJADAH is a savings account with benefits that can be enjoyed at the beginning by obtaining direct prizes without being drawn. This product uses the Wadiah Yad AlDhamanah Agreement and can be withdrawn according to mutual agreement.

d. Fathonah Education Savings (SIDIK Fathonah)

SIDIK FATHONAH is a savings account for students and parents who want to achieve their educational goals perfectly with a profitable $45 \%$ profit sharing. This product uses the Mudlarabah Muthlaqah Agreement which can be deposited at any time and can be withdrawn during the new Academic Year and semester.

e. Hajj and Umrah Savings (SAHARA)

SAHARA is a savings that can make it easier to carry out the Hajj and Umrah pilgrimages by obtaining profit that is generous with a profit sharing of $65 \%$ as an additional provision for the cost of Haj and Umrah. This product uses the Mudlarabah Muthlaqah Agreement with a minimum initial deposit of Rp. 1,000,000, -

\section{f. Eid Savings (SABAR)}

SABAR is a savings that can make it easier to meet the needs of Eid by getting profit from the profit sharing of $55 \%$. This product uses the Mudlarabah Muthlaqah contract with an initial deposit of Rp. 25,000, - and the next deposit is at least Rp. 5,000, -. Deposit at any time while withdrawal can only be made during the Month of Ramadan.

g. Mudlarabah Savings (TABAH)

This product is a savings product that can make it easier to meet daily needs because deposits and withdrawals can be made at any time.

h. Ukhrawi Savings (TARAWI)

TARAWI is a savings account as well as a medium for charity without losing any savings because your savings are donated to the poor and orphans. Using the Mudlarabah Muthlaqah Agreement with an initial deposit of Rp. 25,000, - and the next deposit is at least Rp. 5,000, - with a 50\% share.

Islamic law regulates all aspects of human life as a whole, including all aspects that have to do with that life. The relationship between humans and Allah SWT is regulated in the field of worship, and matters relating to humans and fellow humans in the field of muamalat. Matters relating to the field of muamalat include very broad matters, both individual and general in nature, such as marriage, inheritance, grants and wills, contracts or agreements, constitutional law, criminal, judicial and so on. The number of activities carried out by humans such as buying and selling, ijarah (leasing), mudharabah, syirkah, hiwalah and so on, so that Allah SWT sent down several verses as a guide for humans to carry out business activities carried out in accordance with the provisions of the Sharia. In the Fatwa DSN-MUI Number: 03 / DSN-MUI / IV / 2000 regarding deposits, it is explained that deposits / deposits are allowed and justified, namely the mudharabah principle.

A term deposit with a mudharabah agreement is a collection of funds from the public who entrust their funds to BMT NU Branch of Randuagung Lumajang to be distributed to people in need. These funds are intended to finance various kinds of productive and consumptive businesses that are beneficial for the benefit of the people. This time deposit is a voluntary deposit of members of BMT NU Branch of Randuagung Lumajang, which can only be withdrawn at a time according to the agreement. Mudharabah agreements carried out within the BMT are members of the depositors as shahibul maal or providers of funds and BMT as 
mudharib, who carry out various kinds of activities that are in accordance with shari'ah.

Judging from what form of mudharabah is used in BMT, namely time deposit with the mudharabah contract system is a form of mudharabah time savings, mudharabah time savings, namely savings that are run based on a mudharabah agreement. Mudharabah itself has two forms, namely mudharabah mutlaqah and mudharabah muqayyadah. The difference between the two lies in the presence or absence of requirements given by the owner of funds to the bank in managing their assets. In the implementation in BMT, it can be observed that the mudharabah used is mudharabah mutlaqah, because the saver member as shahibul maal does not provide any conditions to the BMT as the mudarib in carrying out its business activities, the BMT can carry out any business activities that are not against the law. In this case, BMT as mudharib carries out various kinds of business activities that are not against the law, including conducting mudharabah contracts with other parties. However, BMT as the mudharib must not cross the limit of the agreement made together with the saver member as the shahibul maal.

To find out whether or not the implementation of the mudharabah contract at BMT NU Branch of Randuagung Lumajang is valid, you must first look at the pillars. According to the jumhur of scholars, there are three pillars of mudharabah, namely:

a. Aqid, namely the owner of capital

b. Ma'qud alaih, namely capital, power (work) and profit.

c. Sighat, namely ijab and qabul.

In the DSN-MUI Fatwa, the mudharabah requirements are as follows:

a. Providers of funds and managers must be legally competent.

According to Wahbah al-Zuhaili in his book entitled al-Fiqih al-Islami wa Adillatuh, basically the conditions for the two parties to act, the provider of funds (shahibul maal) and the manager (mudharib) must be capable of acting or legally competent, meaning that they must be sensible, mumayiz and baligh, in the mudharabah agreement the two parties to the contract are not required to be Muslim. Both parties with the contract can act independently without any guidance from others. In the application at BMT, the requirements for prospective members, to open an account, must include a KTP (Kartu Tanda Penduduk), that means the person who is a member must be 17 years old or already married. Savers members as shahibul maal must be mature, sensible and mumayiz, these members must have a sound mindset, not crazy. Apart from being required for members as shahibul maal, it is also required on the BMT as mudharib, because in essence the legal subject is not only an individual, but also a legal entity. BMT is an institution that is a legal entity in the form of a cooperative, so BMT is also required, namely that there is a legal BMT establishment deed. In this case, the aqidain has met the requirements as a legal subject, because members (shahibul maal) and BMT (mudharib) are legally competent according to the provisions of syari'at.

b. A statement of consent and qabul must be stated by the parties to show their will in entering into a contract (akad). By paying attention to the following:

1. The offer of acceptance must explicitly indicate the purpose of the contract.

2. Acceptance of the offer is executed at the time of the contract.

3. The contract is stated in writing by correspondence or by using modern methods.

In implementing the ijab qabul at the BMT, the saver members come to the BMT by contacting the teller or the BMT account officer and conveying their desire to save their money in the BMT, the BMT as the mudharib explains some of the savings products along with the procedures and procedures in BMT, after the member who Having understood the provisions, customers who are interested in opening a discounted savings account fill out an application form for opening a time deposit account and fill out a deposit form, then the savings member gives money to $\mathrm{BMT}$ and BMT receives the money. With this, the implementation of the Ijab qabul is in accordance with the provisions of the Shari'ah, because both parties agree and are open to each other without any coercion.

In the case of the implementation of the provision of capital or funds here in the form of money, where the members deposit their funds in the BMT, the amount of money desired by the saver member in cash, which is known to the amount of both parties, is stored in the form of 
time deposits, then proven in the form of bilyet (proof of deposit certificate). In practice, profits or profit sharing received by the saver member as shahibul maal are received in front and directly into the savings account. Where the calculation of the profit is calculated from the capital saved / saved by the member of the saver which is then multiplied by the predetermined ratio of the BMT according to the time period desired by the member of the saver as shahibul maal. So every profit earned by the savings member depends on the funds deposited in the BMT and the time period, not depending on the results of the business carried out. With this practice, the profit sharing ratio is not in accordance with the applicable conditions, namely the profit sharing is not calculated based on the percentage of the profit but rather from the nominal funds or capital of the depositors.

In the practice of business activities by the manager, the saver member as shahibul maal does not supervise the BMT work system as a mudharib, here the saver member as shahibul maal gives his full mandate to the funds to the BMT. In terms of business activities, the saver member as shahibul maal does not provide any conditions for the funds for an activity carried out, the saver member entrusts BMT to carry out business activities. In relation to BMT is a sharia financial institution that is developing at this time, the mudharabah contract that is implemented is BMT only as an intermediary between shahibul maal and mudharib. BMT enters into a mudharabah agreement with another party or a third party or a second mudharabah, wherein the implementation of its business activities BMT adheres to its guidelines, that is, the activity does not contradict the Shari'a. The DSN-MUI Fatwa has explained the general provisions for deposits based on mudharabah in number 2 , it is explained that, "in their capacity as a mudharib, a bank can carry out various kinds of business that do not conflict with the principles of shari'ah and develop it, including conducting mudaraba. with other parties ". The capital that enters the BMT will be used for commercial activities, to finance various kinds of productive and consumptive businesses. So what is carried out by BMT is not prohibited, it fulfills the provisions of the Shari'a, because BMT as a mudharib is considered a representative of the member as shahibul maal who uses or utilizes his capital as appropriate in accordance with the initial agreement, as well as maintaining the trust of the members as shahibul. maal for the capital entrusted to BMT as mudharib and may conduct mudharabah with other parties.

\section{Conclusion}

Based on the results of research and discussion in previous chapters, the authors can conclude as follows:

a. The implementation of the mudharabah contract on time deposits at BMT NU Branch of Randuagung Lumajang is guided by the MUI DSN Number 03 / DSN-MI / IV / 2000 Concerning Deposits, namely the depositors as shahibul maal and the BMT as mudharib, there is a known amount of capital by both parties used for business activities, the existence of business activities carried out by BMT in accordance with sharia, and there is a provision for profit sharing ratios for profit sharing. The mudharabah agreement used is mudharabah muthlaqah, because the depositors do not provide any conditions to the BMT. This mudharabah term deposit comes from people who want to voluntarily save their funds in BMT. The implementation of the profit sharing given by the BMT to the saving members is given in advance / in advance which the profit sharing will go directly to the savings account.

b. From the implementation of the mudharabah contract on time deposits at the BMT NU Branch of Randuagung Lumajang in terms of Islamic law, the implementation of the mudharabah contract on time deposits at BMT NU Branch of Randuagung Lumajang is not appropriate. The mismatch lies on the profit sharing ratio side, the calculation is based on the funds or capital provided by the saving member, this is not in accordance with the conditions that apply to profits, namely that the profit cannot be calculated based on a percentage of the total capital given by the saver member as shahibul maal. , the proportion of profit sharing is calculated only from profit, not including capital. With a defect in the terms of profit, the mudharabah contract becomes fasakh (damaged). Even so, it does not cancel the mudharabah contract on time deposits, the mudharabah contract is still valid, because it is harmonious in its implementation in accordance and fulfilled. 


\section{References}

A Suhaeli Fahmi, Widodo Farid Ma'ruf, T. S. (2015). Kemunduran Mutu Dan Umur Simpan Ikan Teri Nasi Setengah Kering (Stolephorus spp) Selama Penyimpanan Dingin. SAINTEK PERIKANAN : Indonesian Journal of Fisheries Science and Technology, 11(1), 41-46. https://doi.org/10.14710/ ijfst.11.1.41-46

Afkar, T. (2017). Influence Analysis of Mudharabah Financing and Qardh Financing to The Profitability of Islamic Banking in Indonesian. AJIE - Asian Journal of Innovation and Entrepreneurship, 2(3), 340-351.

Astutik, S. (2018). Akad Mudharabah Dalam Perbakan Syariah. MENEJEMEN ASET, 3(2), 1-29.

Hamidah, S., \& Yandono, P. E. (2017). Akad Pembiayaan Mudharabah Menurut Pemahaman Nasabah Baitul Maal Wat Tamwil (Studi Pada BMT Al-Aziz Tongas Probolinggo). Jurisdictie, 7(2), 147. https:// doi.org/10.18860/j.v7i2.3850

Harahap, M. Y. (2008). The Implementation Of Collateral In The Con-Tract Of Mudharabah Financing According To Act No. 21 Of 2008 On Sharia Banking And DSN-MUI's FATWA. Journal of Islamic Studies, 1(1), 1-14.

Heradhyaksa, B., \& Markom, R. (2018). Mudharabah Financing Supervision of Islamic Banking In Indonesian. Diponegoro Law Review, 3(1), 1-14.

Hsb, P. H. (2017). Tinjauan Hukum Islam Terhadap Jaminan Pembiayaan Mudharabah. IJTIHAT, 2(1), 100-117.

Khotijah, S. A. (2020). Analysis of the Effect of Murabaha Finance in Sharia Banks on the Economic Growth of Agricultural Sector. Amwaluna: Jurnal Ekonomi Dan Keuangan Syariah, 4(2), 246-259. https://doi. org/10.29313/amwaluna.v4i2.5432

Lutfiyah Hastuti, Burhanuddin Harahap, S. (2014). Model Perjanjian Efektif Untuk Mengurangi Tingkat Resiko Dalam Pembiayaan Mudharabah Pada Bank Syariah. Yustisia Jurnal Hukum, 3(2), 5-18. https://doi. org/10.20961/yustisia.v3i2.11086
Mas'udah, A. (2017). Akad Mudharabah Dan Murabahah Dalam Perbankan Syariah: Tinjauan Filsafat Hukum. AL HIKMAH, $7(2), 2-10$.

Muhyidin, M. M. S. dan T. (2017). Penerapan Beban Jaminan Akad Mudharabah Di Perbankan Syariah. Diponegoro Private Law Review, 1(1), 114-122.

Muslimah, . (2019). The Effect of Macroeconomic Variables on Non Performing Financing in Shariah Commercial Banks. Journal of Islamic Accounting and Finance Research, 1(1), 250-257. https://doi. org/10.5220/0008439002500257

Putri, A. D. (2020). Konstruksi Hukum Jaminan Pada Akad Mudharabah (Studi di Surakarta).

Qomar, M. N. (2018). Mudharabah Sebagai Produk Pembiayaan Perbankan Syariah Perspektif Abdullah Saeed. MALIA: Journal of Islamic Banking and Finance, 2(2), 201. https:// doi.org/10.21043/malia.v2i2.4890

Trisanty, A. (2018). The Profit Sharing Implementation For Financing In Indonesian Sharia Banking. Airlangga International Journal of Islamics and Finance, 1(1), 32-42.

Usanti, T. P. (2019). Konsep Utang Dalam Akad Pembiayaan Mudharabah Pada Bank Syariah. Journal of Chemical Information and Modeling, 53(9), 1689-1699.

Yuliana, A., \& Bashir, A. (2017). International Journal of Economics and Financial Issues Comparative Analysis of Profit Sharing Financing Between Islamic Banks (BUS) and Islamic Rural Bank (BPRS) in Indonesia. International Journal of Economics and Financial Issues, 7(2), 266-270.

Zaamah. (2019). Analisis Penyelesaian Pembiayaan Bermasalah Di KSPPS BMT NU Jawa Timur Cabang Burneh. 